\title{
VARIASI BENTUK WAJAH LAKI-LAKI DAN PEREMPUAN DARI DESA PANGLIPURAN, KABUPATEN BANGLI, PROVINSI BALI
}

\section{FACE SHAPE VARIATION OF MALE AND FEMALE IN PANGLIPURAN VILLAGE, BANGLI, BALI PROVINCE}

\author{
Agung Eko Cahya Kusuma Putra*, Ni Nyoman Wirasiti, Iriani Setyawati \\ Prodi Biologi F. MIPA Universitas Udayana \\ Email: gungek094@gmail.com
}

Diterima 6 Februari 2016. Disetujui 24 Oktober 2017.

\section{INTISARI}

Penelitian ini bertujuan untuk mengetahui bentuk wajah khas penduduk laki-laki dan perempuan Desa Panglipuran. Analisis bentuk wajah menggunakan metode Geometric Morphometric dan program thin-plate-splin (tps). Pengambilan foto dilakukan dari arah frontal dan lateral dari 18 perempuan dan 14 laki-laki yang berumur 25-35 tahun. Pengambilan foto menggunakan kamera digital Canon EOS 60D. Data diolah lebih lanjut dengan program pengolah foto tpsDig versi 2.04, tpsSuper versi 1.13, tpsRelw versi 1.42, tpsSplin 1.20 dan paket ape serta gee Program R versi 3.2.5. Dalam penelitian ini didapatkan rata-rata tipe wajah laki-laki di Desa Panglipuran berbentuk ellips sedangkan pada perempuan berbentuk bulat. Variasi wajah ditemukan sebanyak 2 tipe wajah frontal dan 2 tipe wajah lateral pada laki-laki, serta 3 tipe wajah frontal dan 3 tipe wajah lateral pada perempuan. Bagian wajah frontal laki-laki dan perempuan yang memiliki variasi tinggi adalah subaurale kanan, subaurale kiri, gonion kanan, gonion kiri, dan gnathion. Sedangkan bagian wajah lateral laki-laki dan perempuan dengan variasi yang tinggi adalah trichion, frontozygomaticus, superciliare, superaurale, pogonion, glabella, titik minimum kurva bawah daun telinga, gonion dan gnathion.

Kata Kunci: analisis wajah, Geometric Morphometric, thin-plate-splin (tps).

\begin{abstract}
This research determined male and female face type of the adults in Panglipuran adults. The analysis of face types Geometric Morphometric Technique in thin-plate-splin (tps) program. Adults female and 14 male aged 25-35 years old were photographed for both frontal and lateral faces with a digital camera Canon EOS 60D. Landmark data was processed by photo processor program tpsDig version 2.04, tpsSuper version 1.13, tpsRelw version 1.42, tpsSplin 1.20 and both of ape and gee package of $\mathrm{R}$ Program version 3.2.5. The average of male's face shape type in Panglipuran village was ellipse and round for female's. We found 2 frontal and 2 lateral for male's face variation, we also found 3 frontal and 3 lateral for female's. Frontal face of male and female that showed high variation included right subaurale, left subaurale, right gonion, left gonion, and gnathion. Lateral face of male and female that showed high variation were trichion, frontozygomaticus, superciliare, superaurale, pogonion, glabella, the minimum point of the curve below earlobe, gonion and gnathion.
\end{abstract}

Keywords: face analysis, Geometric Morphometric, thin-plate-splin (tps).

\section{PENDAHULUAN}

Salah satu suku di Indonesia yang memiliki kebudayaan unik dalam menjaga kelestarian budayanya yaitu suku bali yang berada di Provinsi Bali, yang menganut sistem kasta termasuk dalam hal perkawinan. Suku Bali dapat dibedakan berdasarkan asal usulnya yaitu Bali Majapahit dan Bali Mula (Mantra, 1991). Bali Mula atau Bali Aga mendiami daerah pegunungan sedangkan Bali Majapahit mendiami daerah dataran sehingga disebut Bali Dataran. Perbedaan lain dari keduanya yaitu pada penggunaan bahasa dan struktur masyarakat. Hal ini tampak dari pola kemasyarakatan Bali Dataran yang menganut sistem pelapisan yang dikenal dengan nama kasta atau wangsa (Darsana, 1980; Wiana dan Santeri, 1993; Junitha dan Alit, 2011). Beberapa desa yang termasuk Bali Aga yang tidak menganut sistem kasta yaitu Desa Adat Tenganan, Desa Adat Panglipuran dan Desa Adat Terunyan (Veronica, 2009).

Salah satu Desa Adat Bali Aga dengan keunikan bangunan dan budaya yaitu Desa Panglipuran, terletak di Kabupaten Bangli, Provinsi Bali. Selain itu masyarakat di Desa Panglipuran masih memiliki hubungan kekerabatan antara satu dengan lainnya karena menurut Bendesa Adat Panglipuran (komuni- 
kasi pribadi, 2017), nenek moyang mereka masih menerapkan budaya endogami. Saat ini di Desa Adat Panglipuran warganya sudah diperbolehkan menikah dengan orang dari luar desa (Wayan Supat, Bendesa Adat Desa Panglipuran, Komunikasi pribadi, 2015). Penelitian ini bertujuan mengetahui bentuk wajah khas penduduk desa adat yang termasuk Bali Aga, khususnya di Desa Adat Panglipuran.

\section{MATERI DAN METODE}

Pengambilan sampel dilakukan secara sukarela dan yang termasuk dalam kriteria usia probandus dari umur 25-35 tahun sebanyak 14 laki-laki dan 18 perempuan warga Desa Adat Panglipuran, Kabupaten Bangli, Provinsi Bali. Penentuan usia probandus dari 25-35 tahun untuk menghindari perubahan konstruksi wajah. Mengacu pada penelitian sebelumnya (Candramila, 2014), sampel berupa foto wajah bagian frontal dan lateral. Pengambilan foto secara horizontal dan jarak lensa kamera dari wajah probandus yaitu 2 meter. Foto diambil dari leher sampai dahi bagian atas, dilakukan sebanyak 2 kali dari arah frontal dan lateral. Dalam penelitian ini, pemotretan menggunakan kamera digital Canon EOS 60D dan diusahakan bagian vertex bisa terlihat pada saat pengambilan foto. Foto diberi digitasi landmark sebanyak 36 titik pada bidang frontal dan 24 titik pada bidang lateral yang dilakukan dalam program tpsDig. Hasil tpsDig kemudian diolah dalam tpsSuper untuk menentukan rata-rata tiap wajah. Penghitungan nilai relatif warps (RW) untuk semua sampel wajah frontal dan lateral menggunakan program tpsRelw
(Rohlf, 2005b). Nilai relatif warps dapat digunakan untuk menentukan matriks jarak Euclidean dalam program R (Saitou dan Nei, 1987).

Analisis data selanjutnya dengan paket ape dan paket gee pada program $\mathrm{R}$ akan menghasilkan hubungan antarpola bentuk wajah. Data dikelompokkan dalam bentuk unrooted tree dengan metode Neighbor Joining pada program R (R Development Core team, 2006). Kedekatan tiap sampel diolah kembali dengan tpsSuper untuk mengetahui rata-rata dari tiap variasi wajah laki-laki dan wajah perempuan. Titik-titik landmark yang masih tergabung dalam foto hasil program tpsDig akan dipisah dan dipetakan dalam titik-titik digitasi tersendiri untuk memudahkan pengamatan pergeseran antar titik dengan program tpsSplin (Rohlf, 2004b).

\section{HASIL}

Berdasarkan data dari 14 probandus laki-laki warga Desa Adat Panglipuran didapatkan karakteristik landmark wajah rata-rata bidang frontal berbentuk ellips, gonion kanan dan kiri tumpul dan jaraknya lebar, dagu tumpul, dahi lebar, terdapat penonjolan pada glabella, bagian nasal ke pronasale bergerak ke posterior, pronasale lebih ke atas, zygion tidak terlalu menonjol (Gambar 1.A). Karakteristik landmark wajah rata-rata bidang frontal dari 18 perempuan warga Desa Adat Panglipuran berbentuk bulat, dahi sempit, rahang lebar, gnathion tumpul, penonjolan pada titik glabella, bagian nasal ke pronasale bergerak ke posterior, dan zygion mengarah ke posterior (Gambar 1.B).

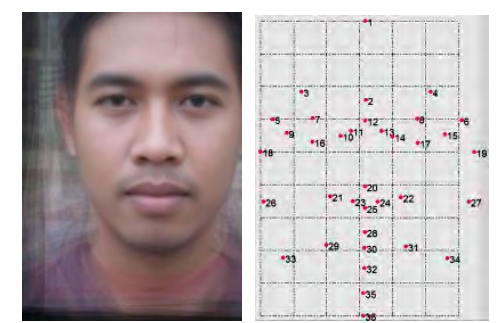

A

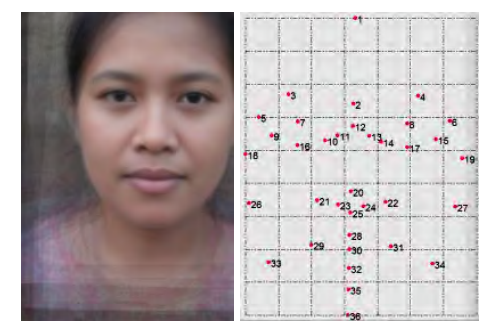

$\mathrm{B}$

Gambar 1. Karakteristik landmark wajah rata-rata bidang frontal pada laki-laki (A) dan pada bidang frontal perempuan (B) dengan menggunakan tpsSuper dan tpsSplin.

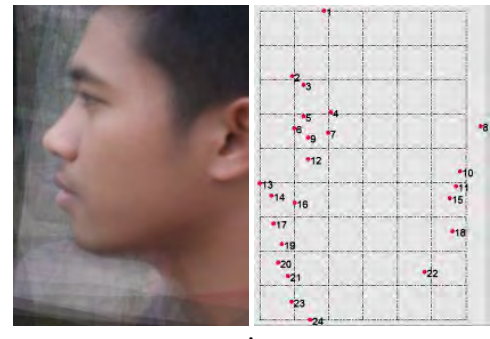

A

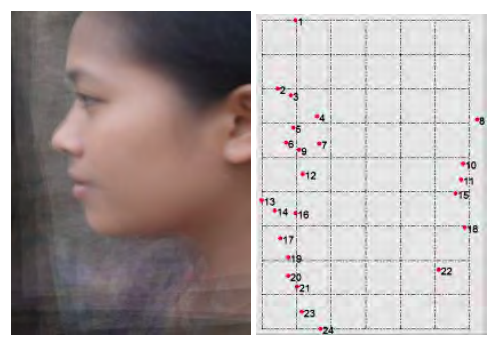

$\mathrm{B}$

Gambar 2. Karakteristik landmark wajah rata-rata bidang lateral pada laki-laki (A) dan pada bidang lateral perempuan (B) dengan menggunakan tpsSuper dan tpsSplin. 
Tabel 1. Nama-nama landmark bagian wajah frontal (Abad, 2002).

\begin{tabular}{|c|c|c|}
\hline No. & Landmark Wajah Frontal & Istilah Indonesia \\
\hline 1 & Trichion & Titik tengah garis rambut pertama \\
\hline 2 & Glabella & Titik pada dahi \\
\hline 3 & Superciliare kanan & Titik maksimum alis mata (kanan) \\
\hline 4 & Superciliare kiri & Titik maksimum alis mata (kiri) \\
\hline 5 & Frontozygomaticus kanan & Akhir alis mata (kanan) \\
\hline 6 & Frontozygomaticus kiri & Akhir alis mata (kiri) \\
\hline 7 & Palpeebrale superius kanan & Titik atas kelopak mata (kanan) \\
\hline 8 & Palpeebrale superius kiri & Titik atas kelopak mata (kiri) \\
\hline 9 & Exocanthion kanan & Pertemuan lateral kelopak mata atas dan bawah (kanan) \\
\hline 10 & Endocanthion kanan & Pertemuan kelopak mata atas dan bawah bagian dalam (kanan) \\
\hline 11 & Maxillofrontale kanan & Titik minimum atau dasar batang hidung (kanan) \\
\hline 12 & Nasale & Titik minimum kurva jembatan hidung \\
\hline 13 & Maxillofrontale kiri & Titik minimum atau dasar batang hidung (kiri) \\
\hline 14 & Endochantion kiri & Pertemuan kelopak mata atas dan bawah bagian dalam (kiri) \\
\hline 15 & Exocanthion kiri & Pertemuan lateral kelopak mata atas dan bawah (kiri) \\
\hline 16 & Palperbrale inferius kanan & Titik bawah kelopak mata (kanan) \\
\hline 17 & Palperbrale inferius kiri & Titik bawah kelopak mata (kiri) \\
\hline 18 & Zygion kanan & Titik paling lateral dari lengkung zigomatik (kanan) \\
\hline 19 & Zygion kiri & Titik paling lateral dari lengkung zigomatik (kiri) \\
\hline 20 & Pronasale & Titik maksimum kurva hidung \\
\hline 21 & Alare kanan & Titik paling lateral dari hidung (kanan) \\
\hline 22 & Alare kiri & Titik paling lateral dari hidung (kiri) \\
\hline 23 & Columella kanan & Titik maksimum lubang hidung (kanan) \\
\hline 24 & Columella kiri & Titik maksimum lubang hidung (kiri) \\
\hline 25 & Subnasale & Pertemuan antara columella dan philtrum \\
\hline 26 & Subaurale kanan & Titik terendah pada batas bawah lobus telinga (kanan) \\
\hline 27 & Subaurale kiri & Titik terendah pada batas bawah lobus telinga (kiri) \\
\hline 28 & Vermelion atas & Perbatasan bibir (atas) \\
\hline 29 & Chelion kanan & Pertemuan lateral antara batas bibir atas dan bawah (kanan) \\
\hline 30 & Stomion & Titik garis tengah antara bibir atas dan bawah \\
\hline 31 & Chelion kiri & Pertemuan lateral antara batas bibir atas dan bawah (kiri) \\
\hline 32 & Vermelion bawah & Perbatasan bibir (bawah) \\
\hline 33 & Gonion kanan & Titik kurva maksimum pada sudut mandibula (kanan) \\
\hline 34 & Gonion kiri & Titik kurva maksimum pada sudut mandibula (kiri) \\
\hline 35 & Pogonion & Titik minimum antara vermilion bawah dengan gnathion \\
\hline 36 & Gnathion & Titik maksimum kurva dagu \\
\hline
\end{tabular}

Tabel 2. Nama-nama landmark bagian wajah lateral (Abad, 2002).

\begin{tabular}{lll}
\hline No. & Landmark Wajah Lateral & Istilah Indonesia \\
\hline 1 & Trichion & Titik tengah garis rambut pertama \\
2 & Glabella & Titik pada dahi \\
3 & Superciliare & Titik maksimum alis mata \\
4 & Frontozygomaticus & Akhir alis mata \\
5 & Palpeebrale superius & Titik atas kelopak mata \\
6 & Nasale & Titik minimum kurva jembatan hidung \\
7 & Exocanthion & Pertemuan lateral kelopak mata atas dan bawah \\
8 & Superaurale & Titik terendah pada batas bawah lobus telinga \\
9 & Palperbrale inferius & Titik bawah kelopak mata \\
10 & Titik maksimum kurva & atas lubang \\
& telinga & Titik maksimum kurva atas lubang telinga \\
11 & Columella & \\
12 & Zigomatik & Titik maksimum lubang hidung \\
13 & Pronasale & Tulang pipi \\
14 & Columella & Titik maksimum kurva hidung \\
15 & Titik minimum kurva bawah lubang & Titik maksimum lubang hidung \\
& telinga & Titik minimum kurva bawah lubang telinga \\
16 & Subnasale & \\
17 & Labiale superius & Pertemuan antara columella dan philtrum \\
18 & Subaurale & Titik median garis vermilion bibir atas \\
19 & Stomion & Titik terendah pada batas bawah lobus telinga \\
20 & Labiale inferius & Titik garis tengah antara bibir atas dan bawah \\
21 & Chin fissure & Titik median garis vermilion bibir bawah \\
22 & Gonion & Titik minimum dari labiale inferus dan pogonion \\
23 & Pogonion & Titik kurva maksimum pada sudut mandibula \\
24 & Gnathion & Titik minimum antara vermilion bawah dengan gnathion \\
& & Titik maksimum kurva dagu \\
\hline
\end{tabular}


Bentuk karakteristik landmark wajah rata-rata bidang lateral pada laki-laki nasale lurus atau mancung, pogonion ke gnathion cenderung tumpul, tulang pipi tidak menonjol dan nasale ke pronasale lurus (Gambar 2.A). Karakteristik landmark wajah rata-rata bidang lateral pada perempuan yaitu hidung tidak mancung yang ditandai dengan pergerakan pronasale ke arah bawah, dari pogonion ke gnathion bergerak ke arah posterior, tulang pipi menonjol dan nasal ke pronasale bergerak ke arah posterior (Gambar 2.B).

Hasil unrooted tree wajah frontal laki-laki (Gambar
3.A.) dan wajah frontal perempuan (Gambar 3.B.) didapatkan 2 tipe variasi wajah bidang frontal laki-laki yaitu tipe I (A1) 7 probandus dan tipe II (A1) 7 probandus. Sementara dari total 18 probandus perempuan didapatkan 3 tipe variasi wajah bidang frontal perempuan yaitu tipe I (B1) 7 probandus, tipe II (B2) 6 probandus, dan tipe III (B3) 5 orang probandus. Dalam penelitian ini hanya didapatkan jumlah sampel yang sedikit karena banyak penduduk (kategori probandus) tidak dapat ditemui karena bekerja atau bersekolah di kota dan tinggal di luar Desa Panglipuran.

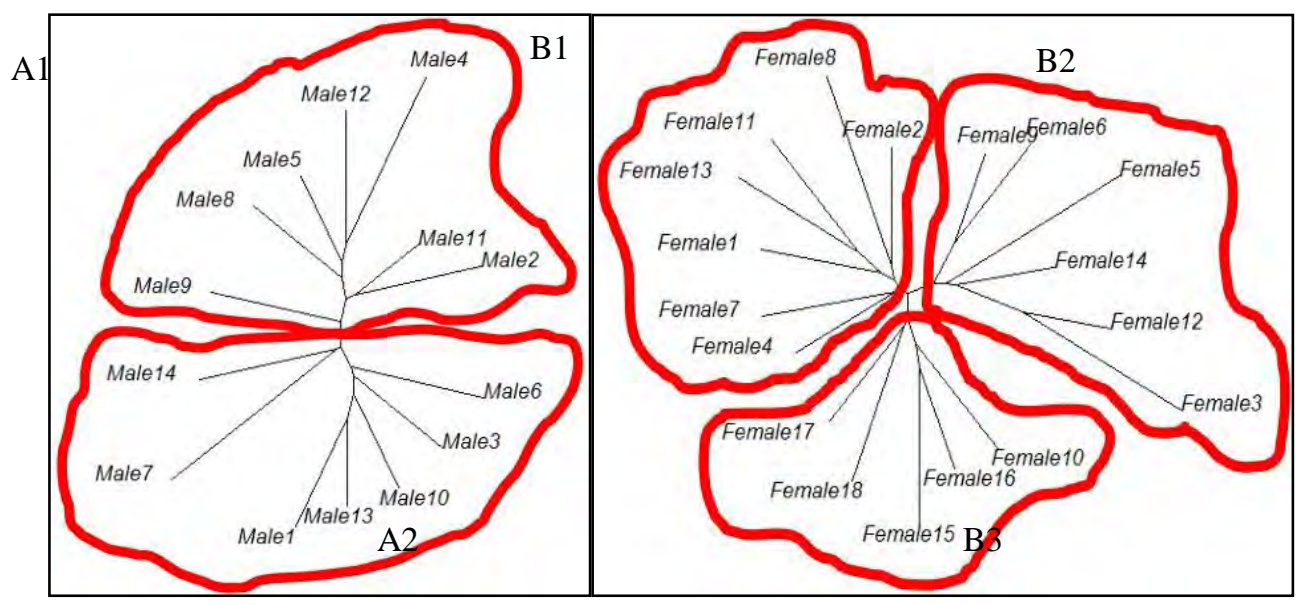

Gambar 3. Unrooted tree wajah frontal laki-laki tipe I (A1), tipe II (A2) dan unrooted tree wajah frontal perempuan tipe I (B1), tipe II (B2), dan tipe III (B3), paket ape dan paket gee, program R.
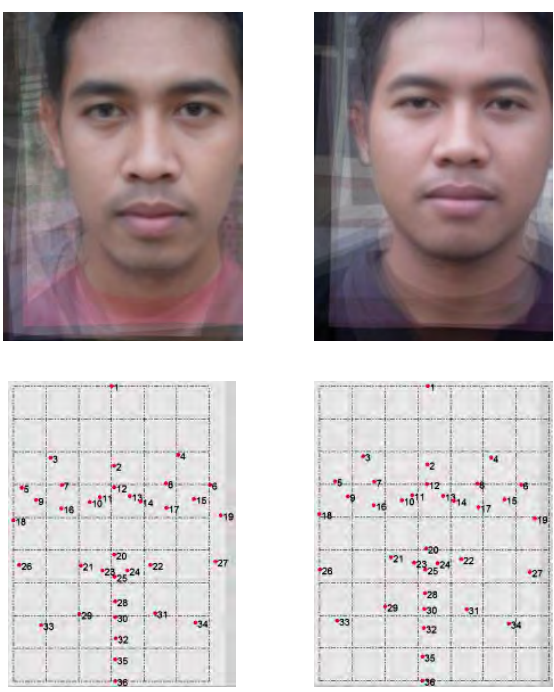

A1

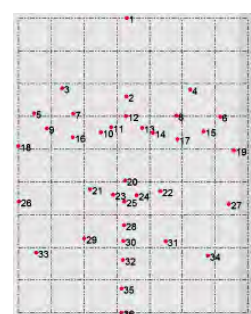

A2
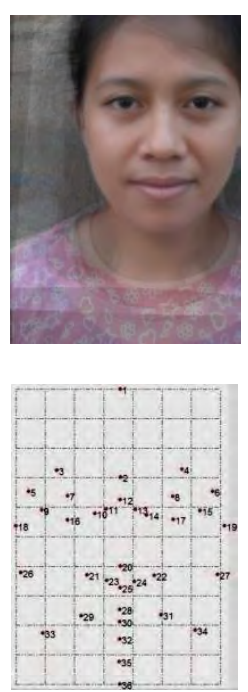

B1
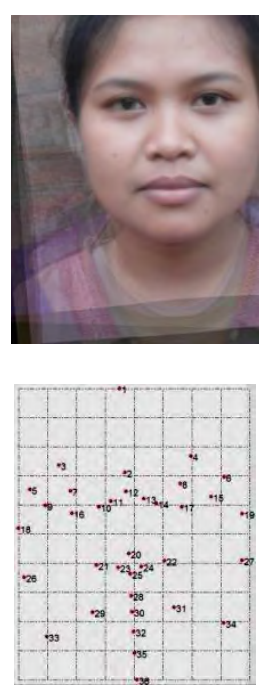

B2
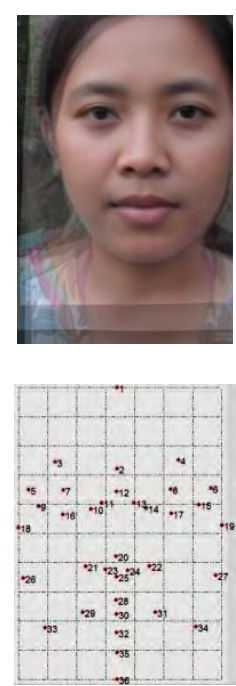

B3

Gambar 4. Karakteristik landmark wajah frontal laki-laki pada tipe I (A1), tipe II (A2) dan karakteristik landmark wajah frontal perempuan tipe I (B1), tipe II (B2), tipe III (B3). 
Karakteristik landmark wajah bidang frontal pada laki-laki Tipe I yaitu wajah cenderung panjang, dahi lebar, tulang pipi atau zygion tidak menonjol. Wajah sempit yang ditandai dengan dekatnya jarak subaurale kanan dan subaurale kiri, rahang tidak lebar ditandai dengan jarak gonion dengan subaurale yang pendek, dagu lebih pendek. Tipe I frontal lakilaki ini memiliki bentuk wajah ellips (Gambar 4.A1.). Karakteristik landmark wajah bidang frontal pada laki-laki Tipe II yaitu wajah cenderung pendek, hidung tidak mancung yang ditandai dengan pergerakan pronasale ke arah bawah, tulang pipi menonjol, rahang besar. Tipe II frontal laki-laki memiliki bentuk wajah ellips (Gambar 4.A2.).

Karakteristik landmark wajah bidang frontal pada perempuan Tipe I yaitu wajah cenderung pendek, dahi relatif sempit, wajah tidak lebar, hidung mancung ditandai dengan pergerakan pronasale ke arah atas, zygion menonjol, rahang tidak lebar, dagu panjang dan memiliki bentuk wajah ellips (Gambar
4.B1.). Karakteristik landmark wajah bidang frontal pada perempuan Tipe II adalah tinggi wajah sedang, dahi lebar, wajah lebar, zygion atau tulang pipi tidak menonjol, rahang lebar, dagu pendek serta memiliki bentuk wajah bulat (Gambar 4.B2.). Karakteristik landmark wajah bidang frontal pada perempuan Tipe III yaitu wajah cenderung panjang, dahi lebar, lebar wajah sedang, zygion atau tulang pipi tidak menonjol, hidung kurang mancung yang ditandai dengan pergerakan pronasale ke arah bawah. rahang lebih lebar dari tipe lain, dagu paling panjang dan memiliki bentuk wajah ellips (Gambar 4.B3.).

Hasil unrooted tree wajah lateral laki-laki (Gambar 5.A.) dan lateral perempuan (Gambar 5.B.) didapatkan 2 tipe variasi wajah bidang lateral laki-laki yaitu tipe I (Gambar 5.A1.) 8 probandus dan tipe II (Gambar 5.A2.) 6 probandus. Dari total 18 probandus perempuan didapatkan 3 tipe variasi wajah bidang lateral perempuan yaitu tipe I (Gambar 5.B1.) 6 probandus, tipe II (Gambar 5.B2.) 5 probandus, dan tipe III (Gambar 5.B3.) 7 orang probandus.

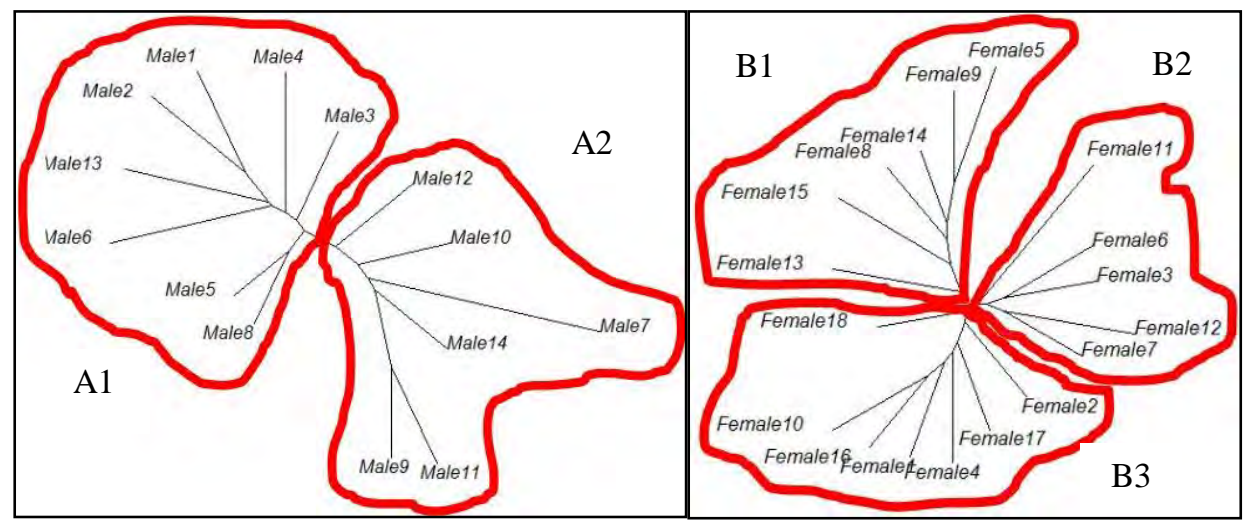

Gambar 5. Unrooted tree pada bidang lateral pada laki-laki tipe I (A1), tipe II (A2) dan pada bidang lateral perempuan tipe I (B1), tipe II (B2), tipe III (B3), dengan menggunakan paket ape dan paket gee, program R.

Karakteristik landmark wajah bidang lateral pada laki-laki Tipe I yaitu wajah kecil, hidung mancung yang ditandai pergerakan pronasale ke arah atas, tulang pipi menonjol, rahang kecil, bibir tipis dan dagu bergerak ke arah belakang sehingga tampak panjang (Gambar 6.A1.). Karakteristik landmark bidang lateral laki-laki Tipe II yaitu wajah panjang, hidung tidak mancung ditandai dengan pergerakan pronasale ke arah bawah, tulang pipi tidak menonjol, rahang besar, bibir tebal, dagu bergerak ke arah depan (Gambar 6.A2.).

Karakteristik landmark wajah bidang lateral pada perempuan Tipe I yaitu wajah besar, hidung tampak mancung ditandai dengan pergerakan pronasale ke bawah, tulang pipi menonjol, bibir tebal, rahang tampak sempit, dan dagu yang bergerak ke belakang
(Gambar 6.B1). Karakteristik landmark wajah bidang lateral pada perempuan Tipe II yaitu wajah kecil, hidung kurang mancung, tulang pipi tidak menonjol, rahang tampak lebar, bibir tipis dan dagu bergerak ke depan (Gambar 6.B2.). Karakteristik landmark wajah bidang lateral pada perempuan Tipe III yaitu tinggi wajah sedang, hidung kurang mancung yang ditandai dengan pergerakan pronasale ke bawah, tulang pipi menonjol, rahang tampak lebar, bibir tipis dan dagu bergerak ke arah belakang (Gambar 6.B3.).

Variasi tertinggi wajah terbentuk oleh penyebaran paling luas dari titik landmark. Anak panah hitam menunjukkan bagian yang memiliki tingkat variasi tertinggi pada wajah. Variasi tertinggi ditandai oleh titik yang memiliki tingkat penyebaran terluas (Gambar 7.). 


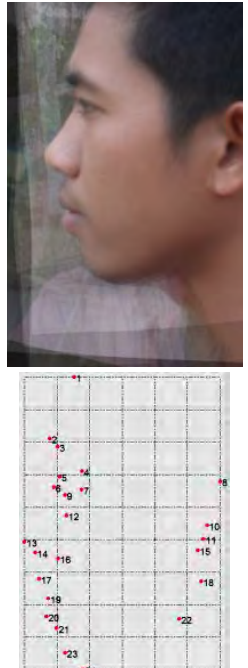

A1

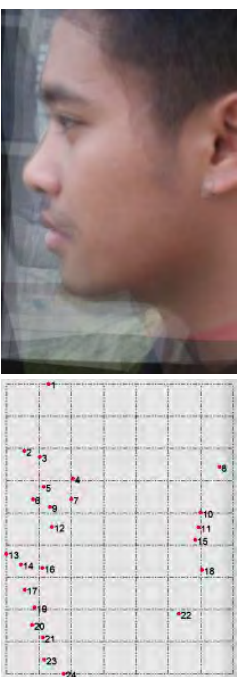

A2

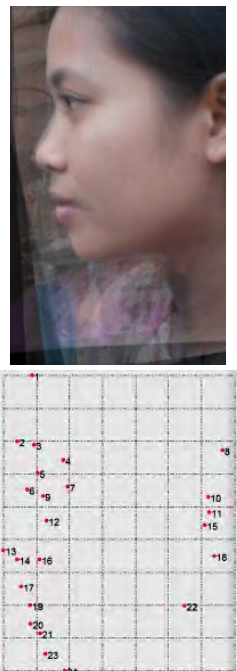

B1

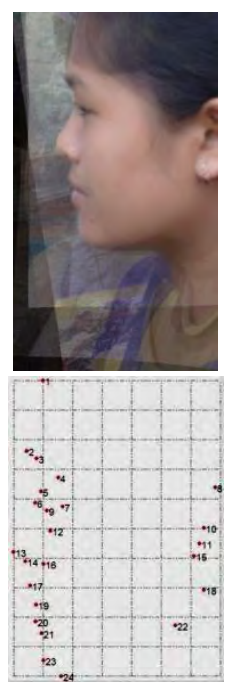

B2

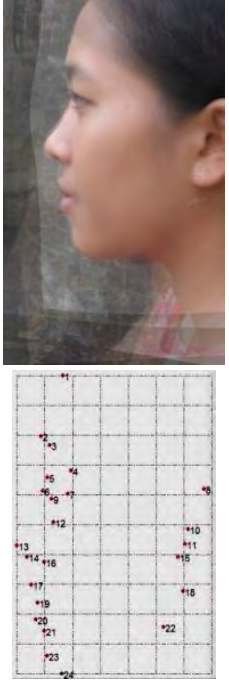

B3

Gambar 6. Wajah bidang lateral pada laki-laki tipe I (A1), tipe II (A2) dan wajah bidang lateral pada perempuan tipe I (B1), tipe II (B2), tipe III (B3).

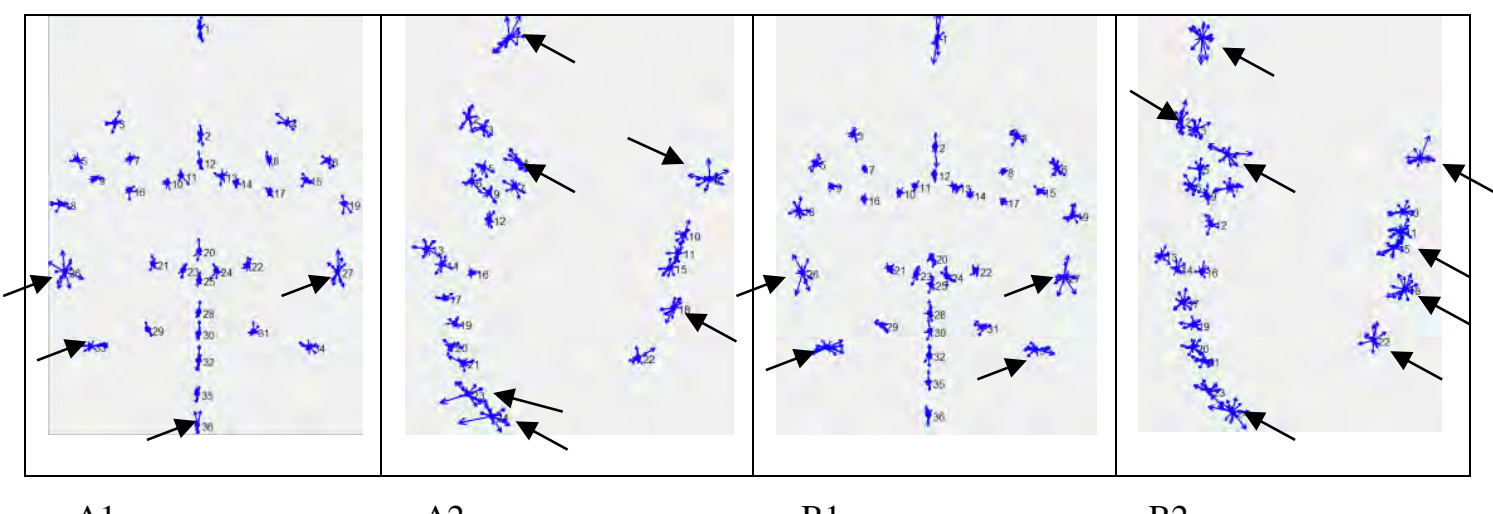

A1

A2

B1

B2

Gambar 7. Plot vektor yang menunjukkan tingkat variasi wajah tertinggi pada karakteristik landmark bidang frontal pada wajah laki-laki (A1) serta bidang lateral pada wajah laki-laki (A2) dan vektor yang menunjukkan tingkat variasi wajah tertinggi pada karakteristik landmark bidang frontal pada wajah perempuan (B1) dan serta bidang lateral pada wajah perempuan (B2) dalam program tpsSuper.

Bagian frontal wajah pada laki-laki memiliki variasi tertinggi pada titik 26, 27, 33, dan 36 (Gambar 7.A1), sementara pada perempuan memiliki variasi tertinggi pada titik 1, 26, 27, 33, dan 34 (Gambar 4.11.B1). Bagian lateral wajah pada laki-laki memiliki variasi tertinggi pada titik 1, 4, 8, 18, 23, dan 24 (Gambar 4.11.A2), sementara pada perempuan memiliki variasi tertinggi pada titik 1, 2, 4, 8, 15, 18, 22, dan 24 (Gambar 4.11.B2). Nama dari tiap landmark dapat dilihat pada Tabel 1 (wajah bidang frontal) dan Tabel 2 (wajah bidang lateral).

\section{PEMBAHASAN}

Hasil penelitian menunjukkan perbedaan wajah ratarata dari arah frontal antara laki-laki dan perempuan dilihat dari trichion laki-laki lebih lebar daripada perempuan, glabella laki-laki lebih menonjol, nasale pada perempuan berbentuk cekung sedangkan pada laki-laki bentuknya lurus, antara vermelion atas ke vermelion bawah pada laki-laki lebih tipis daripada perempuan dan vermelion bawah laki-laki lebih tebal dari vermelion perempuan, bentuk dagu pada laki-laki lebih tumpul dan lebar sedangkan pada perempuan cenderung meruncing. Perbedaan wajah rata-rata bidang lateral yaitu pada glabella laki-laki lebih menonjol, subaurale laki-laki lebih lebar dan tebal daripada perempuan, pogonion ke gnathion perempuan lebih tajam yang menyebabkan gonion terlihat jelas dan lebih runcing. Titik maksimum kurva bagian atas lubang telinga, tragus, dan titik minimum kurva bawah tulang telinga pada keduanya memiliki ukuran yang 
relatif sama. Ukuran hidung laki-laki lebih besar daripada perempuan.

Berdasarkan pengolahan 14 wajah laki-laki dan 18 wajah perempuan warga Desa Adat Panglipuran, didapatkan hasil 2 tipe wajah frontal dan 2 tipe wajah lateral pada laki-laki serta 3 tipe wajah frontal dan 3 tipe wajah lateral pada perempuan. Perbedaan wajah frontal laki-laki tipe I dan II terletak pada tinggi wajah, dagu, hidung, tulang pipi, dan rahang. Perbedaan wajah frontal tipe I, tipe II dan tipe III perempuan terletak pada bentuk wajah, lebar dahi, lebar wajah, hidung, tulang pipi, rahang dan dagu. Perbedaan pada wajah lateral laki-laki tipe I dan tipe II terletak pada bagian tinggi wajah, hidung, tulang pipi, rahang, lebar bibir dan dagu. Perbedaan wajah lateral perempuan tipe I, tipe II dan tipe III yaitu terletak pada bagian tinggi wajah, hidung, tulang pipi, rahang, bentuk bibir dan dagu. Berdasarkan tipe variasi wajah pada laki-laki dan perempuan warga Desa Adat Panglipuran pada penelitian ini hanya ditemukan sedikit variasi. Hal ini menunjukkan bahwa perkawinan yang mengarah ke endogami tidak mempengaruhi banyaknya tipe variasi wajah yang ditemukan pada keturunannya. Hasil ini tidak berbeda dengan penelitian lain yang sudah pernah dilakukan di beberapa daerah lain.

Beberapa penelitian terdahulu ditemukan 3 tipe wajah frontal dan 3 tipe wajah lateral pada laki-laki warga Kampung Naga, Tasikmalaya, sebagai desa yang masih menerapkan sistem perkawinan endogami di Jawa Barat (Abad, 2002). Penelitian Candramila (2014) yang membandingkan Suku Sunda dengan Suku Jawa didapatkan hasil 5 tipe wajah frontal perempuan, 5 tipe wajah lateral perempuan, 4 tipe wajah frontal laki-laki dan 4 tipe wajah lateral laki-laki. Penelitian tipe wajah pada Suku Batak di Kabupaten Tapanuli Selatan, Padangsidempuan dan Tapanuli Utara, Sumatera Utara menemukan 5 tipe wajah baik wajah frontal maupun lateral pada laki-laki, sedangkan pada perempuan ditemukan 4 tipe wajah frontal dan 3 tipe wajah lateral (Siregar, 2009). Penelitian lain menemukan 3 tipe wajah untuk laki-laki dan perempuan suku Minangkabau (Putri, 2016). Penelitian terhadap warga perkampungan Suku Betawi, Jakarta Selatan, menemukan 2 tipe wajah laki-laki dan 2 tipe wajah perempuan. Hasil yang sama juga ditunjukkan pada variasi wajah etnis Betawi yang termasuk daerah urban di Perkampungan Budaya Betawi Setu Babakan dengan pola perkawinan yang membaur. Hal ini menunjukkan bahwa pola perkawinan yang mengarah ke endogami tidak mempengaruhi pembentukan variasi wajah (Lestari, 2010). Pernyataan Lestari (2010) sejalan dengan hasil yang diperoleh dari Desa Panglipuran dalam penelitian ini.
Bagian-bagian wajah laki-laki yang berjumlah 14 probandus dan perempuan yang berjumlah 18 probandus di Desa Panglipuran yang menunjukkan variasi yang tinggi untuk wajah frontal laki-laki (Gambar 7.A1.) pada bagian subaurale kanan (26), subaurale kiri (27), gonion (33), dan gnathion (36). Bagian lateral wajah laki-laki (Gambar 7.A2.) pada bagian trichion (1), frontozygomatycus (4), superaurale (8), subaurale (18), pogonion (23), dan gnathion (24). Bidang frontal perempuan (Gambar 7.B1.) pada bagian trichion (1), subaurale kanan (26), subaurale kiri (27), gonion kanan (33), dan gonion kiri (34). Bidang lateral perempuan (Gambar 7.B2.) pada bagian trichion (1), glabella (2), frontozygomaticus (4), superaurale (8), titik minimum kurva bawah daun telinga (15), subaurale (18), gonion (22) dan gnathion (24).

Penelitian sebelumnya menemukan variasi pada tinggi wajah, lebar wajah, glabella, hidung, dagu dan rahang pada bentuk wajah laki-laki Kampung Naga yang masih menganut sistem perkawinan endogami (Abad, 2002). Ditemukan variasi wajah meliputi tinggi wajah, lebar wajah, glabella, hidung, dagu dan rahang pada penduduk perkampungan Betawi di daerah Jakarta Selatan (Lestari, 2010). Sedangkan pada populasi mahasiswa IPB dari Suku Minangkabau ditemukan variasi bentuk wajah pada bagian wajah, hidung, dagu, dahi, rahang, dan tulang pipi (Putri, 2016). Variasi bentuk wajah laki-laki dan perempuan Suku Batak di Kabupaten Tapanuli Selatan, Padangsidempuan dan Tapanuli Utara, Sumatera Utara menunjukkan variasi pada tinggi wajah, lebar wajah, glabella, gnathion, dan gonion. Variasi tertinggi merupakan suatu kondisi di mana terdapat penyebaran titik yang luas di satu landmark (Siregar, 2009), umumnya berkaitan dengan variasi akibat faktor genetik.

\section{SIMPULAN}

Rata-rata tipe wajah laki-laki di Desa Panglipuran berbentuk ellips, sedangkan pada perempuan berbentuk bulat. Tipe variasi wajah ditemukan 2 tipe wajah frontal dan 2 tipe wajah lateral pada laki-laki, serta 3 tipe wajah frontal dan 3 tipe wajah lateral pada perempuan. Bagian wajah frontal laki-laki dan perempuan yang memiliki variasi yang tinggi adalah bagian trichion, subaurale kanan, subaurale kiri, gonion kanan, gonion kiri, dan gnathion. Sedangkan bagian wajah lateral laki-laki dan perempuan dengan variasi yang tinggi adalah bagian trichion, glabella, frontozygomatycus, superciliare, titik minimum kurva bawah daun telinga, superaurale, subaurale, pogonion, gonion dan gnathion. 


\section{UCAPAN TERIMA KASIH}

Penulis menyampaikan rasa terima kasih kepada warga Desa Panglipuran, Kabupaten Bangli, Provinsi Bali yang telah memberikan bantuan serta dukungan selama peneliti melakukan penelitian di lingkungan Desa Adat Panglipuran.

\section{KEPUSTAKAAN}

Abad, B. 2002. Variasi Wajah Laki-laki Kampung Naga. Program Studi Biologi. Institut Pertanian Bogor. (Skripsi). Tidak dipublikasikan.

Candramila, W. 2014. Variasi Biologi Orang Sunda di Pulau J awa Bagian Barat. Program Studi Biologi. Institut Teknologi Bandung.(Disertasi) Tidak dipublikasikan.

Darsana, I.G.P. 1980. Tenganan Pegringsingan: Segisegi Megalitiknya. (Pertemuan Ilmiah Arkeologi) J akarta.

Junitha, I. K. dan I. B. Alit. 2011. Ragam Alel Mikrosatelit DNA Autosom pada Masyarakat Bali Aga Desa Sembiran Kabupaten Buleleng Bali. Biota.

Lestari, D. 2010. Variasi Wajah Laki-laki dan Perempuan Betawi Di Perkampungan Budaya Betawi Setu Babakan. Institut Pertanian Bogor. (Skripsi). Tidak dipublikasikan.

Mantra, I. B. 1991. Landasan Kebudayaan Bali. Denpasar: Yayasan Dharma Sastra.

Putri, W. E. 2016. Morfometrik Wajah Orang Minangkabau. Program Sarjana. Institut
Pertanian Bogor. (Skripsi). Tidak dipublikasikan.

R Development Core Team. 2006. A Language and Environment for Statistical Computing Version 3.2.5. R Foundation for Statistical Computing, Viena-Austria.

Rohlf, F. J. 2004a. tpsSuper Version 1.13. Department of Ecology and Evolution, State University of New York, Stoony Brook, New York.

Rohlf, F. J. 2004b. tpsSplin Version 1.20. Department of Ecology and Evolution, State University of New York, Stoony Brook, New York.

Rohlf, F. J. 2005a. tpsDig Version 2.04. Department of Ecology and Evolution, State University of New York, Stoony Brook, New York.

Rohlf, F. J . 2005b. tpsRelw Version 1.42. Department of Ecology and Evolution, State University of New York, Stoony Brook, New York.

Saitou, N. and Nei, M. 1987. The Neighbor-joining Method" A New Method for Recronstructing Phylogenetic Trees. Molecular Biology and Evolution 4:406-425.

Siregar, M. A. 2009. Variasi wajah Suku Batak. Program Pascasarjana. Institut Pertanian Bogor. (Tesis). Tidak dipublikasikan.

Veronica, A. K. dan Damayanti, S. 2009. Pola perumahan dan pemukiman Desa Tenganan Bali. Manado. Jurusan Arsitektur. Universitas Sam Ratulangi.

Wiana, K. dan Santeri, R. 1993. Kasta dalam Hindu Kesalahpahaman Berabad-abad. Denpasar. Yayasan Dharma Naradha. 